\title{
THE DETERMINANT OF MCMORAN STOCK PRICE
}

\author{
Resky Harisma Rumbiak ${ }^{* 1}$, Noer Azam Achsani*), Trias Andati**) \\ *) School of Business, IPB University \\ Jl. Padjajaran, Bogor, Indonesia 16151, Indonesia \\ ${ }^{* * *}$ PPM Jakarta \\ Jl. Menteng Raya No.9 Menteng, Jakarta 10340, Indonesia
}

\begin{abstract}
The Purpose of this paper is to research the determinant of fundamental factors consisting of Net Profit Margin (NPM), Return on Equity (ROE), Return on Asset (ROE), Earning per Share (EPS), Working Capital Turn Over (WCTO) and external factors namely: oil prices, gold prices, the Fed's interest rate and systematic risk, and also Indonesia government regulation towards FCX stock prices. This paper utilizes the ECM analysis methodology, the data during the period of 2000-2019, are obtained from quarterly financial statements issued to the Security Exchange Commission (SEC), the internet for share and commodity prices and also created dummy variable to accommodate the impact of Indonesia government regulation (MINERBA LAW). The results indicate that fundamental and external factors simultaneous have a significant influence on FCX stock prices. Partially in the long-term ROA, gold prices and world oil prices have a significant positive effect, while the Fed Rate and government policies have a significant negative effect. In the short term, the price of oil, gold and WCTO has a significant positive effect, while ROE has a significant negative effect.
\end{abstract}

Keywords: external factors, fundamental factors, minerba law, mining company, stock price

Abstrak: Tujuan dari makalah ini adalah untuk meneliti faktor-faktor penentu fundamental terdiri dari Net Profit Margin (NPM), Return on Equity (ROE), Return on Asset (ROE), Earning per Share (EPS), Working Capital Turn Over (WCTO) dan faktor eksternal, yaitu harga minyak, harga emas, suku bunga the Fed dan risiko sistematis, peraturan pemerintah Indonesia terhadap harga saham FCX. Penelitian ini menggunakan metode Error Correction Model (ECM) dengan periode data pada tahun 2000 s.d 2019, diperoleh dari laporan keuangan kuartal yang dilaporkan kepada badan pengawas pasar modal di Amerika atau SEC,media internet untuk mendapatkan harga saham dan harga komoditas serta membuat variabel dummy untuk mengetahui pengaruh dari kebijakan pemerintah Indonesia (UU MINERBA). Hasil peneitian ini menujukan faktor fundamental dan eksternal secara simultan memiliki pengaruh signifikan terhadap harga saham FCX. Secara parsial dalam jangka panjang ROA, harga emas dan harga minyak dunia memiliki pengaruh positif signifikan, sedangkan Fed Rate dan kebijakan pemerintah memiliki pengaruh negatif signifikan. Dalam jangka pendek harga minyak, emas dan WCTO memiliki pengaruh positif signifikan sedangkan ROE memiliki pengaruh negatif signifikan

Kata kunci: faktor eksternal, faktor fundemental, uu minerba, perusahan tambang, harga saham

${ }^{1}$ Corresponding author:

Email: resky.harisma@gmail.com 


\section{INTRODUCTION}

The extraordinary fluctuations of world oil prices from 2008 to 2015 followed by the fluctuation in world commodity prices and the uncertainty of American economic conditions after the subprime mortgage financial crisis, trade relations with China and unclear tax policies turn the economic prospects of America in the future cannot be predicted by the market, according to the world bank business outlook 2019. (Broadstock and Filis, 2014) revealed that compared to China, the United States is the country with the highest level of influence on oil price shocks which makes share prices, especially on the S\&P 500 index, responsive to the oil price movement.

Freeport McMoRan is one of the companies listed on the New York Stock Exchange (NYSE) under the ticker symbol "FCX" and has operating areas in various countries including Indonesia through PT. Freeport Indonesia (PTFI) must be able to provide positive sentiments for market players since essentially investors put some money or capital in the hope that the money will increase (May 2011). The movement of stock prices is expected to produce a return or profit consisting of (a) capital gain or the difference between the selling price and the purchase price of shares per sheet divided by the purchase price and (b) dividend yield or dividend per share divided by the purchase price of shares per sheet ( Zubir, 2011). Market players use fundamental analysis, technical analysis, and news as a tool to analyze the shares of the capital market (Wijaya 2014).

Earning is perceived by the financial users as the primary determinant of the firm's equity value (Sumiyana et al. 2010). The relationship of fundamental factors such as PER, EPS, NPM, PBV partially has a significant and positive effect on the price of shares listed on the Indonesian stock exchange (Pudji, 2017), this is with under the research of (Iqbal et al. 2013) which revealed a positive relationship of fundamental factors with stock returns in Pakistan. Research by (Haghiri and Haghiri, 2012) revealed a significant relationship between ROE and ROA on stock returns on the Tehran stock exchange. While in the mining sector registered in Indonesia, (Sakinah, Chumaidiyah and Zulbetti, 2016) revealed the effect of ROA, ROE, NPM, EPS, and macroeconomic factors simultaneously have a significant influence. Research conducted by (Sha, 2017), (Avdalović and Milenković, 2017), (Imran et al. 2014), (Djalil, Tabrani and Jalaluddin, 2017) show that there is a significant effect of PER and NPM on stock prices. While for the use of working capital (Duggal and Budden, 2015) revealed in their research on the S\&P 500 stock index, that companies who use less net working capital will reduce the cost of capital and increase their market value.

Wijaya (2014) explains the fundamental analysis is an in-depth analysis that focuses on the financial statements by looking at some various aspects such as profitability (profit), solvability (liability vs assets), liquidity (the ability to pay off short-term debt), and activity (business continuity). May (2011) further explains the fundamental analysis including information about the company's financial and health reports, company management, competitors, and the market situation of the product. Fundamental analysis is used to make financial predictions that include current and historical data. With various targets such as directing stock prices and predicting the movements of the relevant stock prices, projecting company performance, management evaluations, and risk calculations. Meanwhile, technical analysis is an analysis of stock price movements through historical data which includes an opening, closing, highest price, lowest price, and volume of a stock at any time by using diagrams to assess markets, stocks, or other financial instruments (Nison, 2003). Other than that public information or news which is information provided to all investors may affect the stock price when the information is announced (Sumiyana, 2007).

Apart from internal factors, external factors such as world gold prices, world oil prices, and US bank interest rate policies influence stock prices. Research conducted by (Toraman, Başarır and Bayramoğlu, 2011) revealed a negative and significant correlation was found between gold return and USA dollar return, a positive correlation was found between gold return and oil return. (Mumtaz and Smith, 2019) explaining the policy of the American Central Bank (The Fed) has a diverse effect on developing countries, Europe, and capital markets in America. Research using the Markov-Switching model explains that there are two different periods of the influence of the Fed on the variables examined from 1994 to 2017, namely (1) a period of economic expansion and (2) economic recession. (Harun, 2002) explained that government policies have a significant influence on stock returns, especially policies that were not anticipated before by the market. This is under research conducted by 
(Singh, 2015) which explains that in the long run, the composite stock index price on the Indian stock market shows a positive correlation with government policy through interest rates.

Government policy was another factor that made news for market participants who influenced on market sentiment. In the study conducted by (Subeniotis et al. 2011) on European stock markets, it was explained that there was a positive relationship between the stock market with sentiment indicators and market capitalization. (Durham, 2005) stated that overall, the effect of government monetary policy on the stock market in the United States makes the stock market fluctuate.

Some topics that exist in capital market research in accounting include several things such as the earnings response coefficient and the characteristics of analyst forecasts, fundamental analysis, and valuation research, as well as market efficiency tests (Kothari, 2001). Research conducted by (Egam, Ilat and Pangerapan, 2017) using multiple linear regression to see the effect of ROA, ROE, NPM EPS on stock prices listed on the LQ45 index for the period 2013-2015 revealed that ROA and ROE do not have a negative effect, NPM has a negative effect and EPS has a positive effect on stock prices in LQ45 . (Park and Ratti, 2008) using the VAR model revealed a significant effect of oil price shocks on stock prices in the United States and 13 European countries. This is under research conducted by (Sadorsky, 1999), (Hatta and Dwiyanto, 2012), (Davis and Haltiwanger, 1999) who revealed that oil price fluctuations have a significant effect on the stock market in America. (Raraga and Muharam, 2013) by using the VAR / VECM method, revealed that there is a cointegration relationship between world gold prices, world oil prices, stock price indexes, and exchange rates on IDX. In other words, there is a long-term relationship between these variables. (Joshi, 2009) revealed the relationship of SENSEX stock price index, an exchange rate (Rupee / Dollar), and crude oil prices in India have a high econometric relationship to the price of gold. (Srinivasan and Prakasam, 2015) used the ARDL and Granger Causality methods on gold prices, stock prices, and currency exchange rate changes in India from 1990 to April 2014, explained that the price of gold, stock prices, and exchange rates tend to have a long-term reciprocal relationship. (Hidayat, Firdaus and Sanim, 2019) conducted research on the effect of the stock market and macroeconomic capitalization on stock prices in the 2008-2017 period using ECM revealed that stock market capitalization, oil prices, gold prices and the Hang Seng index in general, have a positive and significant effect on the IDX, only inflation has a significant negative effect. In the short-term estimation, the influencing variables are stock market capitalization, inflation, world oil prices and the Hang Seng Index, while world gold prices do not effect. The stock market capitalization and the Hang Seng Index have a positive effect. Meanwhile, inflation and world oil prices have a negative effect.

Similar to previous research, researchers used financial ratio variables as fundamental influences, namely NPM, ROE, ROA, WCTO and EPS, and added macroeconomic variables such as the Fed rate, world gold prices and world oil prices as external factors. And for the difference with previous research is researchers included non-economic variables which is government policies (Minerba Law) as a dummy variable. In addition, researchers with a relatively long time, where previous research used about 2 to 10 years with the object of the stock index, researchers used 19 years of data, focus on 1 stock price using the ECM method to determine the effect of variables in the short and long term. This is expected to be an input for investors or capital market players as well, conduct the same study before opening a buy/sell position on other stocks.

Research also discovers systematic risk denote by beta (B). (Brigham dan Housten, 2011) explained there are two kinds of risk in the capital market, (1) Systematic risk is a market risk faced by all companies and cannot be removed, and (2) Unsystematic risk faced by certain companies which can be removed or minimized. Systematic risk is measured by a beta coefficient $(\beta)$, this indicator is also a measurement to show the imminence of individual profit rate of a certain stock to the change of market index profit rate (Hatta and Dwiyanto, 2012). (Horne, 2002) explained beta is the slope of the Security Market Line (SML) between the return of a stock and the market. (Sulistyorini, Hartoyo and Andati, 2016) explained to estimate beta several theories can be used as single-index model and CAPM model, both can be done through regression technique. (Drobetz, Menzel and Schröder, 2016) conducted a study on systematic risk behaviour in the international shipping/shipping industry, explaining that beta shows the fundamental risks of companies, based on the 
panel data regression model it is said that systematic risk is determined by macroeconomic conditions and industry level. (Kazi, 2008) using a VAR analysis of the cointegration relationship between systematic risk factors in the Australian capital market, explained bank interest rates, company profitability, dividend yields, production factors and long-term changes in the global market affect stock returns in the distant future. Based on observations, all variables have cointegration although partially not all variables have a significant effect.

The reason authors added the Indonesian government policy towards PTFI as a variable is because PTFI has a significant role in FCX business continuity, according to financial reports published by FCX in 2019, PTFI that operates in Tembagapura mine area, Mimika, Papua, Indonesia, have a total reserve of 35.6 billion pounds of copper, equivalent to $31 \%$ of FCX's total copper reserves which is 116 billion gold punch and reserves of 29.1 million ounces, or about $98 \%$ of FCX's total gold reserves, equal to 29.6 million ounces, contributing around $55 \%$ to the average total FCX consolidated revenue from 2017 to 2019. In September 2018 Indonesia through the mining holding company PT. Inalum officially acquired of PTFI, which made Indonesia obtain the right to a $51 \%$ stake on PTFI and making the Freeport company with many factors of interest to the United States and Indonesia.

Freeport McMoRan's stated lose on their financial statements for the period of 2014 to 2016 with a total of around USD 16.8 million after Freeport's acquired of two oil and gas companies, Plains Exploration Production and McMoRan Exploration, at the end of 2012 valued at USD 20 billion including debts. In the period of 2014-2015 world crude oil prices dropped to reach the lowest level of USD 37 per barrel. The movement of FCX stock prices experienced a downtrend from 2011 to 2016 (Bearish). The decline was confirmed by two other mining companies which are Newmont (NEW) and Neucor (NUE) in 2014. FCX's share price touched the lowest level of $\$ 4.6$ per share in January 2016, FCX's share price rebound could only be at $\$ 11.92$ at the end of 2018, this value is much lower than the average value of the previous FCX shares in the range of USD 40 /share. The condition was worsened by the concentrate export ban on PT. Freeport Indonesia in 2014 impact of the 2009 mineral and coal policy in
Indonesia (Minerba Law). which made the sustainability of Freeport McMoRan's business to become uncertain. As an efficiency measure, FCX restructures its board of directors by reduced the number of directors, evaluated capital expenditures, and separated its mining operations from oil and gas business operations.

Those things make researchers interested in conducting this research and the authors want to present comprehensive information to all stakeholders regarding the current financial condition of FCX and external factors that can affect FCX's share price as part of decision-making information.

Based on the background described, the purpose of this research is to study the determinant of fundamental and external factors toward FCX stock prices Than formulate the managerial recommendations for stakeholders. Variable under study is Net Profit Margin (NPM), Return on Equity (ROE), Return on Asset (ROA), Earning per Share (EPS), Working Capital Turn Over (WCTO) and External Factors which are The Fed Rate, Gold Price, Oil Price, systematic risk (Beta) from 2000 through 2019 and dummy variables for the Indonesian government regulations. All variables studied is a statistically selected variable and econometric as well as a representation of the whole fundamental and macroeconomic variables that have been described

\section{METHODS}

The types and sources of data used in this study are secondary data, by calculating the ratio of NPM, ROE, ROA, EPS, and WCTO obtained from Freeport McMoRan's financial statements (fcx.com) for the period 2000 to 2019 published to Securities Exchange and Commission (SEC) quarterly. The prices for FCX shares, world oil, and gold were obtained from yahoo. finance.com and investing.com which are processed quarterly using closing prices. Then, the interest rates of US federal banks are obtained from federalreserve. gov. Meanwhile, systematic risk data were obtained by calculating the slope between FCX stock returns and market returns (S\&P 500) denoted by beta $(\beta)$, and the addition of dummy variables for the Indonesian government's Minerba Law towards PTFI. 
Time series data were used in this research and financial ratio to calculate the fundamental factors, Error Correction Model (ECM) to analyze data using Microsoft Excel and Eviews 10 software to process the data. ECM was used for variables that have nonstationary but cointegrated data, ECM has restrictions. his restriction is added because the data is non-stationary but has cointegration so that restrictions are utilized by ECM on the existing long-term variable relationships so that they converge into their cointegration relationships and still allow dynamic changes in the short term, hence in ECM, there is a speed of adjustment from short to long term (Firdaus, 2011)

Figures 1 are presented in characteristic line with difference betas, according to Horne (2002) to find the slope a portfolio's beta is simply a weighted average of the individual stock betas in the portfolio, with the weights being the proportion of total portfolio market value represented by each stock. This is consistent with (Alena, Achsani and Andati, 2017) who researched on sector beta index by calculating the variation in stock returns and market returns. Thus the beta of a stock represents its contribution to the risk of a highly diversified portfolio of stocks. SML is a line that connects the expected level of return of security with systematic risk. The assessment on beta is divided into several conditions such as $\beta=1$ (stock gains and losses equal to market gains and losses). $\beta>1$ (stock gains and losses are greater than market gains and losses), $\beta<1$ (stock gains and losses are smaller than market gains and losses).

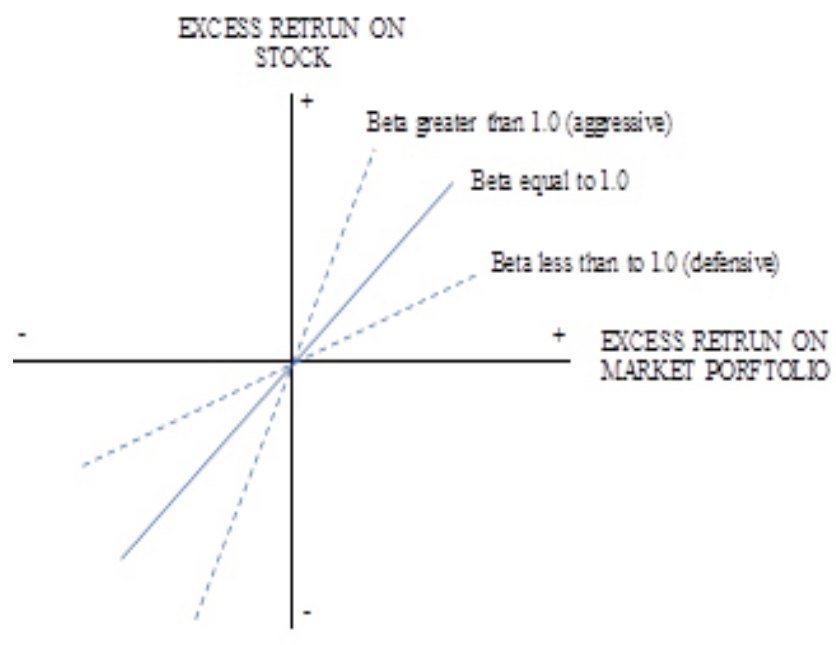

Figures 1. Characteristic line with difference betas
Before we start to produce the data there are several tests that should be done, which are: (a) Stationarity Test is the first step in processing time-series data because non-stationary data will give an unfavourable impact on the estimated model due to heteroscedasticity and autocorrelation, this can cause spurious regression. Estimation of data stationaery can be done by looking at graphs to determine trends, using autocorrelation and correlogram tests or unit root tests or unit root tests (Juanda and Junaidi, 2012). In this study, the unit root test was used using the Augmented Dickey-Fuller (ADF). The data can be stationary when the t-ADF absolute value is greater than the absolute MacKinnon value and the probability value is less than the real level of $5 \%$. If the data processed has unit roots, then the data is not stable, so the tests at the level stage are performed again at the first difference to the second difference stage. (b) Cointegration Test, the purpose of the cointegration test is to determine the long-run equilibrium or the long-term relationship between variables that are not stationary before differentiation. Even though individual variables are not stationary, a linear combination of two or more time series can be stationary (Gujarati, 2004). Variables that are initially stationer but have cointegration can cause the regression equations meaningful and not spurious regression (Juanda and Junaidi, 2012). Cointegration testing can be done in several ways including the Johansen cointegration test, the Durbin-Watson cointegration test, and the Engle-Granger cointegration test.

The cointegration test used in this study was the Johansen cointegration test. The equation is cointegrated if the Trace statistic is greater than the Critical Value (Firdaus, 2011). After the number of the cointegrated equation was found, the next analysis was the Error Correction Model (ECM) analysis

\section{Error Correction Model}

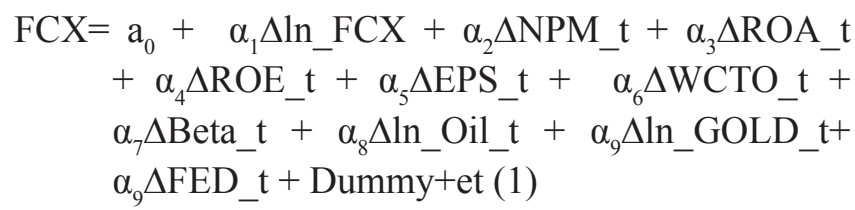

The long-run equation in model (1) is non-stationary will result in spurious regression, the meaning less meaningful. Furthermore, the model is formed into a model dynamic by including inaction or which is called the error correction model. Correction model is written as follows: 
$\begin{aligned} \mathrm{FCX}= & \mathrm{a}_{0}+\alpha_{1} \Delta \ln \_\mathrm{FCX}+\alpha_{2} \Delta \mathrm{NPM} \mathrm{t}+\alpha_{3} \mathrm{ROA} \mathrm{t} \\ & +\alpha_{4} \Delta \mathrm{ROE} \_\mathrm{t}+\alpha_{5} \Delta \mathrm{EPS} \mathrm{t}+\alpha_{6} \Delta \mathrm{WCTO} \mathrm{t} \\ & +\alpha_{7} \Delta \text { Beta_t }+\alpha_{8} \Delta \ln { }_{-} \mathrm{O} \mathrm{H}_{-} \mathrm{t}+\alpha_{9} \Delta \ln - \\ & \text { GOLD_t }+\alpha_{9} \Delta \text { FED_t }+ \text { Dummy-Y } \mathrm{u}_{\mathrm{t}-1}+\text { et }\end{aligned}$ (2)

Equation (2) is a Error Correction Model (ECM) because of the inclusion of an Error Correction Term (ECT) that is characteristic of ECM. If the ECT coefficient is significant statistic at probability less than $5 \%$, this model is valid.

Information: In_FCX (FCX's stock prices); ln_GOLD= Gold prices);In_Oil(Oil Prices (WTI)); NPM(Net Profit Margin); ROA (Return on Asset); ROE (Return on Equity); WCTO (Working Capital Turnover Ratio); EPS (Earning per Share); FED (Interest Rate the Fed).

\section{Statistical Test}

We used the statistical test to test the analysis whether the independent variables have a significant effect on the dependent variable. This significant test analysis uses partial and simultaneous tests.

\section{Partially Test}

There are two possibilities regarding the significance of a regression coefficient which is equal to zero and not equal to zero. Tests are carried out to partially determine the independent variables which have a significant effect on the dependent variable. The test is carried out using a one-sided test, with the hypothesis as follows:

$\mathrm{H} 0$ : $\beta \mathrm{i}=0$, meaning that there is no significant positive or negative effect of the independent variable on the dependent variable

Ha: $\beta \mathrm{i}<0$ or $\beta \mathrm{i}>0$. There is a significant negative or positive effect of the independent variable on the dependent variable.

The test criteria are if the value of $\mathrm{t}_{\text {count }}>\mathrm{t}_{\text {table }}$ or the probability of ttest $\alpha<0.05$ then $\mathrm{H} 0$ is rejected or accepts Ha, meaning that the independent variable has a significant negative or positive effect on the dependent variable; If the value of tcount $<$ ttable or the probability of ttest $\alpha>0.05$ then $\mathrm{H} 0$ is accepted or rejected by Ha, meaning that the independent variable does not have a significant negative or positive effect on the dependent variable
Simultaneous Test (F Test)

To find out simultaneously the independent variable has significant or insignificant effect on the dependent variable, there are two-side test is carried out with the following hypothesis:

$\mathrm{H} 0: \beta 0=0$, meaning that there is no significant effect of the independent variable.

Ha: at least on $\beta i \neq 0$. There is a significant effect of the independent variable on the dependent variable.

The test criteria are if the value of Fcount $>$ Ftable or the probability of Ftable $\alpha<0.05$ then $\mathrm{H} 0$ is rejected or accepts $\mathrm{Ha}$, meaning that the independent variables together have a significant effect on the dependent variable; If the value of Fcount $<$ Ftable or the probability of Ftable $\alpha>0.05$ then $\mathrm{H} 0$ is accepted or rejected by $\mathrm{Ha}$, meaning that the independent variables Simultaneous haven't a significant effect on the dependent variable.

This research approached with the determination of the most common fundamental and external indicators affecting stock prices, consisting of Net Profit Margin (NPM), Return on Equity (ROE), Return on Assets (ROA), Earning per Share (EPS) and Working Capital Turn Over (WCTO), systematic risk (Beta), gold prices, oil prices and the American central bank (The Fed) rates included dummy variable for government regulation in 2009. After that, calculations are made on financial ratios such as NPM, ROE, ROA, EPS, WCTO and stock beta. After obtaining the results of the calculation of ratios and natural logarithms of stock, gold and oil prices, then the variables are calculated through the ECM model to gain influence on the short and long term as a basis for providing managerial recommendations which are presented in research framework (Figures 2).

Based on early research, the hypothesis of the behaviour of McMoRan stock price in this study as follows:

H1,0 : Fundamental and External Factors simultaneously have not significant impact to FCX stock price

H1,a : Fundamental and External Factors simultaneously have significant impact to FCX stock price

H2,0 : Fundamental Factors partially have not significant impact toward FCX Stock Price

H2,a : Fundamental Factors partially have significant 
impact toward FCX Stock Price

$\mathrm{H} 3,0$ : External Factors partially have not significant impact toward FCX Stock Price

H3,a : External Factors partially have significant impact toward FCX Stock Price

Authors expect are: (a) Fundamental factors and external factors simultaneously have significant impact towards FCX stock price, (b) fundamental factors partially have a significant impact towards FCX stock prices, and (c) all external factors partially have significant impact towards FCX stock prices.

\section{RESULTS}

\section{Data Stationarity Test}

The initial stage of this research was to test the stationarity of the data by conducting a unit root test of each variable using the Augmented Decky Fuller test. Based on the results of the data obtained as shown in Table 1, the variables are not stationary at the stage level, so the test must be continued at the first difference stage which addresses all stationary variables.

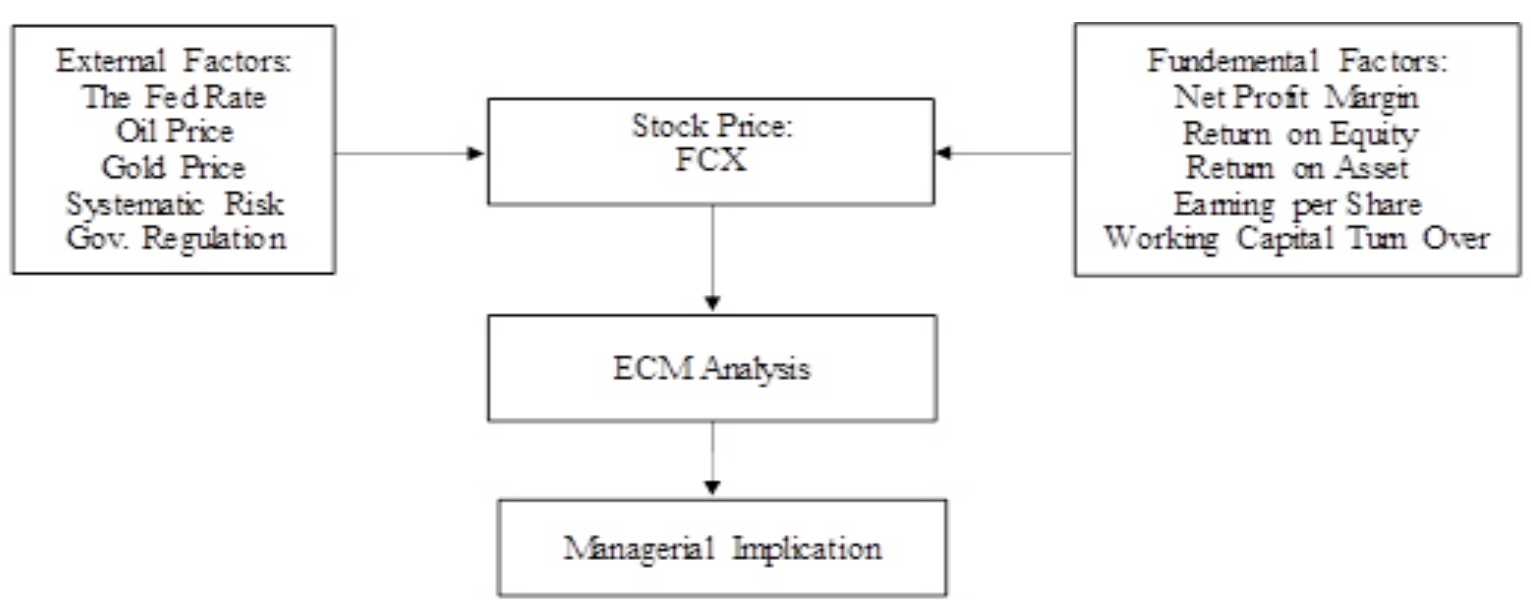

Figures 2. Research frameworks

Table 1. Data Stationarity Test

\begin{tabular}{lcccc}
\hline Variable & \multicolumn{2}{c}{ Level } & \multicolumn{2}{c}{ First Difference } \\
\cline { 2 - 5 } & T-ADF & Prob & T-ADF & Prob \\
\hline LN_FCX & -2.064485 & 0.2595 & -7.895442 & $* 0.0000$ \\
Net Profit Margin (NPM) & -8.112646 & $* 0.0000$ & -10.05625 & $* 0.0000$ \\
Return on Equity (ROE) & -7.853223 & $* 0.0000$ & -9.866948 & $* 0.0000$ \\
Return on Assets (ROA) & -7.670477 & $* 0.0000$ & -9.774970 & $* 0.0000$ \\
Earnings Per Share (EPS) & -8.551072 & $* 0.0000$ & -8.363959 & $* 0.0000$ \\
Working Capital Turnover & -3.992259 & $* 0.0024$ & -15.62871 & $* 0.0001$ \\
Systematic Risk (Beta) & -6.686425 & $* 0.0000$ & -10.64654 & $* 0.0001$ \\
\hline FED Rate & -4.348535 & $* 0.0008$ & -3.425988 & $* 0.0130$ \\
LN_Gold & -1.481692 & 0.5377 & -8.634484 & $* 0.0000$ \\
LN_Oil & -2.186582 & 0.2128 & -8.142618 & $* 0.0000$ \\
Dummy & -1.094289 & 0.7146 & -8.831761 & $* 0.0000$ \\
\hline
\end{tabular}

Information: *Stationer at the 0.05 level 


\section{Cointegration Test}

The cointegration test with the Johansen test was conducted to determine whether there is a long-term influence of the model can be seen in Table 2. This is to determine whether the ECM stage can be continued or not. When there is cointegration then the ECM stage can be continued but if there is no cointegration then VAR analysis is used. The Cointegration test result showed that there was 10 cointegration indicated by the trace test value greater than the critical value of $5 \%$ so that the analysis is continued to the Johansen cointegration test

\section{Long Run Affecting Factors Estimate}

Long-term estimation results from the ECM model that analyses the influence of fundamental and external factors consisting of NPM. ROA, ROE, EPS, WCTO, gold price, oil price, Fed rate, systematic risk and government policy on FCX stock prices can be seen in
Table 3. R-Squared or determination coefficient (R2) of 0.912269 means that all independent variables in the model can explain $91.23 \%$ of the dependent variable variations while the remaining $8.77 \%$ is explained by other variables outside the model. The relationship of this influence is significant at the $1 \%$ level. This can be seen from the probability value of the F-statistic $0.000000<1$ means simultaneously all variables have a significant effect. This is under research conducted by (Sakinah, Chumaidiyah and Zulbetti, 2016) which stated ROA, ROE, NPM and EPS; Inflation, BI Rate, and the dollar exchange rate have a simultaneously significant effect on Stock Return on the mining sector listed on the IDX in 2010-2014, (Raharjo and Muid, 2013) revealed simultaneously ROE, ROA, DER, CR, EPS and BVS showed a positive and significant effect on stock price changes, (Manoppo, Tewal and Jan 2017) who revealed CR, DER, ROA and NPM simultaneously have a significant effect on stock prices. Partial testing of the influence of the dependent variable. As follows:

Table 2. Cointegration Test

\begin{tabular}{lccccccccccc}
\hline Hypothesized & \multicolumn{10}{c}{ At Most } \\
\cline { 2 - 12 } No. of CE(s) & None & 1 & 2 & 3 & 4 & 5 & 6 & 7 & 8 & 9 \\
\hline Trace Statistic & 561.15 & 457.96 & 372.62 & 295.48 & 222 & 160.91 & 109.05 & 66.15 & 30.11 & 11.36 \\
0.05 Critical Value & 239.23 & 197.37 & 159.52 & 125.61 & 95.75 & 69.81 & 47.85 & 29.79 & 15.49 & 3.84 \\
Prob.** & 0.00 & 0.0001 & 0.00 & 0.00 & 0.00 & 0.00 & 0.00 & 0.00 & 0.0002 & 0.0007 \\
\hline
\end{tabular}

Information: Trace test indicates 10 cointegrating eqn(s) at the 0.05 level

Table. 3 Long Run Affecting Factors Estimate

\begin{tabular}{|c|c|c|c|c|}
\hline Variable & Coefficient & Std. Error & t-Statistic & Prob. \\
\hline \multicolumn{5}{|c|}{ Fundamental Factors: } \\
\hline NPM & -0.14006 & 0.25549 & -0.54820 & 0.5853 \\
\hline $\mathrm{ROA}$ & 6.52366 & 2.87066 & 2.27253 & $0.026 * *$ \\
\hline ROE & -1.18682 & 1.22853 & -0.96605 & 0.3374 \\
\hline WCTO & 0.00166 & 0.00225 & 0.73853 & 0.4627 \\
\hline EPS & -0.00106 & 0.00825 & -0.12836 & 0.8982 \\
\hline \multicolumn{5}{|l|}{ External Factors: } \\
\hline FED_RATE & -9.97497 & 2.15534 & -4.62803 & $0.0000 * * *$ \\
\hline LN_GOLD & 0.51613 & 0.19133 & 2.69764 & $0.0088 * * *$ \\
\hline LN_OIL & 1.14725 & 0.13475 & 8.51410 & $0.0000 * * *$ \\
\hline BETA & 0.00562 & 0.02801 & 0.20077 & 0.8415 \\
\hline DUMMY & -0.59915 & 0.17629 & -3.39863 & $0.0011 * * *$ \\
\hline $\mathrm{C}$ & -4.96586 & 0.82755 & -6.00067 & $0.0000 * * *$ \\
\hline R-squared & 0.912269 & \multicolumn{2}{|c|}{ Prob(F-statistic) } & 0.000000 \\
\hline
\end{tabular}

Information: $* * *$ ) Significant at the $1 \%$ level; $* *$ ) Significant at the $5 \%$ level; ${ }^{*}$ ) significant at the $10 \%$ level 


\section{The Influence of Fundamental Factors}

The effect of ROA on FCX stock price has a regression coefficient of 6.523657 with a significant positive direction at the $5 \%$ level with a probability value of $0.0262<5 \%$, so this study rejects the hypothesis $\mathrm{H} 0$ : $\beta 0$ $=0$, and accepts the hypothesis Ha: $\beta \mathrm{i}>0$. This means that the independent variable ROA has a significant positive effect on FCX's share price. This means that in the long run every $1 \%$ increase in ROA will increase the FCX share price by $6.5 \%$ and other variables are considered constant. This study is in line with the research of (Haghiri and Haghiri, 2012) which states that the ROA ratio has a high correlation with stock returns at all industries levels. And in line with the research of Modigliani and Miller (MM) which states that company value is determined by the earning power of company assets (Visconti, 2018) and (Manoppo, Tewal and Jan 2017) which state that ROA has a significant positive effect on stock prices.

\section{The Influence of External Factors}

The effect of Fed Rate on FCX stock price has a regression coefficient of -9.974973 with a significant negative direction at the $1 \%$ level with a probability value of $0.0000<1 \%$, so this study rejects the hypothesis H0: $\beta 0=0$, and accepts the hypothesis Ha: $\beta \mathrm{i}<0$. This means that the independent variable Fed Rate has a significant negative effect on FCX stock prices. This means that in the long run, every $1 \%$ increase in the Fed's interest rate will reduce the FCX share price by $-9.97 \%$, ceteris paribus. This research is in line with Tatom (2002) who revealed a negative relationship between the S\&P 500 stock price and the Fed interest rate.

The effect of the gold price on the FCX stock price has a regression coefficient of 0.516126 in a positive direction, significant at the $1 \%$ level with a probability value of $0.0088<1 \%$, so this study rejects the hypothesis H0: $\beta=0$, and accepts the hypothesis Ha: $\beta 1>0$. This means that the independent variable the price of gold has a significant positive effect on the stock price of FCX. This means that in the long-run, every $1 \%$ increase in the price of gold will increase the FCX share price by $0.52 \%$, ceteris paribus. This research is in line with (Srinivasan and Prakasam, 2015b) which revealed that the long run co-integration relationship between stock price and gold price in India, (Suharno and Indarti, 2014) which revealed that Indonesia's bank interest rates, world oil prices and gold prices had an effect on the IDX. And (Hidayat, Firdaus and Sanim, 2019) disclose the significant positive effect of gold prices on the IDX.

The effect of oil prices on stock prices FCX has a regression coefficient of 1.147249 with a positive direction. Significant at the $1 \%$ level with a probability value of $0.0000<1 \%$, this study rejects the hypothesis H0: $\beta=0$ and accepts hypothesis Ha: $\beta \mathrm{i}>0$. This means that the independent variable oil price has a significant positive effect on FCX stock prices. This means that in the long run every $1 \%$ increase in oil prices will increase FCX's share price by $1.15 \%$, ceteris paribus. This research is in line with (Arfaoui and Ben Rejeb, 2017) which state that the US stock market has a positive effect on oil and gold prices and (Syarif and Asandimitra, 2015) who disclose that oil prices have a significant positive effect on the IDX.

The influence of government policy which is symbolized by the dummy variable has a regression coefficient of -0.599147 with a negative direction, significant at the $1 \%$ level, so this study rejects the hypothesis $\mathrm{H} 0: \beta=0$ and accepts hypothesis Ha: $\beta \mathrm{i}<0$. This means that the independent dummy variable has an effect. significant negative impact on FCX's share price. A change in the dummy variable of $1 \%$ affects $-0.6 \%$ of the FCX stock price, ceteris paribus. This is in accordance with the research of (Harun, 2002) which states the anticipated and unanticipated components of monetary policy have significantly different effects on the stock market returns. The unanticipated component of the monetary policy results in a larger short-term effect with a small long-term effect on the stock market. On the other hand, the anticipated component of the monetary policy results in a smaller short-term effect with a large longterm effect.

\section{Short Run Affecting Factors Estimate}

The short-term estimation results from the ECM model that analyses the influence of fundamental and external factors on FCX stock prices can be seen in Table 4. The requirement for a good ECM model is that the ECT coefficient value (-1) is between -1 and 0 and is significant (Prob. $<0.05$ ). Hidayat et al. (2019) the requirements of the ECM model have been met because the resulting ECT Error Correction Term coefficient $(-1)$ is -0.672702 and the Prob (F-statistic) 0.00000 is less than 0.05 , indicating that the previous period 
disequilibrium was corrected in the current period by $67 \%$. That is mean if there is a disturbance (shock) the adjustment process (Adjustment Mechanism Process) on the long-term equilibrium lasts for $1 / 0.672702=$ 1 quarter.

R-squared (R2) of 0.527977 means that all independent variables can explain the dependent variation of 53\% while the remaining $47 \%$ is explained by other variables outside the model. Simultaneously all independent variables have an effect and are significant at the $1 \%$ level. The F-Statistic probability value is 0.000000 less than 0.01. Partial testing of the influence of the dependent variable. As follows:

\section{The Influence of Fundamental Factors}

The effect of ROE on FCX stock price has a regression coefficient of -1.581329 with a negative and significant direction at the $10 \%$ level. It can be seen from the probability value of $0.0623<10 \%$. This study rejects the hypothesis $\mathrm{H} 0: \beta 0=0$ and accepts the hypothesis Ha: $\beta<0$. This means that in the short term each $1 \%$ increase in ROE will reduce the FCX share price by $-1.58 \%$, ceteris paribus. The results of this study are in line with the research of (Wijayanti and Sulasmiyati, 2016) which revealed a significant negative effect of ROE on mining companies listed in securities and different from (Raharjo and Muid, 2013) who revealed that ROE was not significant at LQ 45 share price.
The influence of WCTO on FCX stock price has a regression coefficient of 0.002215 with a negative and significant direction at the $10 \%$ level. It can be seen from the probability value of $0.0916<10 \%$. This study refutes the hypothesis $\mathrm{H} 0: \beta 0=0$ and accepts the hypothesis Ha: $\beta>0$. This means that in the short term every $1 \%$ increase in WCTO will increase the FCX share price by $0.002 \%$, ceteris paribus. the results of this study are in accordance with the theory the greater use of net working capital will increase the firm's cost of capital and lower its market value (Duggal and Budden, 2015).

The Influence of External Factors

The effect of the gold price on the FCX stock price has a regression coefficient of 0.637316 with a positive and significant direction at the $10 \%$ level. It can be seen from the probability value of $0.0579<10 \%$. This study refutes the hypothesis $\mathrm{H} 0: \beta 0=0$ and accepts the hypothesis Ha: $\beta>0$. This means that in the short term every $1 \%$ increase in the price of gold will increase the FCX stock price by $0.64 \%$, ceteris paribus. The results of this study are in line with (Suharno and Indarti, 2014) who revealed that the Indonesian bank interest rate, world oil prices and gold prices influence the IDX. And (Hidayat, Firdaus and Sanim, 2019) disclose the significant positive effect of gold prices on the IDX.

Table 4. Short run affecting factors estimate

\begin{tabular}{lcccc}
\hline Variable & Coefficient & Std. Error & t-Statistic & Prob. \\
\hline Fundamental Factors: & & & \\
\hline D(NPM) & 0.200514 & 0.15916 & 1.259828 & 0.212 \\
D(ROA) & 3.223139 & 2.064911 & 1.560909 & 0.1232 \\
D(ROE) & -1.581329 & 0.834438 & -1.895082 & $0.0623^{*}$ \\
D(WCTO) & 0.002215 & 0.001294 & 1.711283 & $0.0916^{*}$ \\
D(EPS) & 0.002652 & 0.004367 & 0.607190 & 0.5457 \\
\hline External Factors: & & & \\
\hline D(FED_RATE) & -5.51937 & 5.454026 & -1.011981 & 0.3151 \\
D(LN_GOLD) & 0.637316 & 0.330399 & 1.928929 & $0.0579^{*}$ \\
D(LN_OIL) & 0.755636 & 0.143679 & 5.259210 & $0.0000^{* * *}$ \\
D(BETA) & $6.02 \mathrm{E}-06$ & 0.017086 & 0.000352 & 0.9997 \\
D(DUMMY) & 0.033506 & 0.304202 & 0.110145 & 0.9126 \\
C & -0.007412 & 0.022649 & -0.327245 & 0.7445 \\
\hline R-squared & 0.527977 & Prob(F-statistic) & 0.000000 \\
\hline
\end{tabular}

Information: ***) Significant at the $1 \%$ level; $* *$ ) Significant at the $5 \%$ level; $*$ ) significant at the $10 \%$ level 
The effect of oil prices on FCX stock prices has a regression coefficient of 0.755636 with a positive and significant direction at the $1 \%$ level. It can be seen from the probability value of $0.00000<1 \%$. This study refutes the hypothesis H0: $\beta 0=0$ and accepts the hypothesis Ha: $\beta>0$. This means that in the short term every $1 \%$ increase in oil prices will increase the FCX share price by $0.76 \%$, ceteris paribus. This research related to Subing, Kusumah and Gusni (2017) research on stock prices in Indonesia revealed that the relationship between the increase in oil prices has a significant effect because the increase in oil prices tends to trigger an increase in almost all sectors on the stock market. with (Arfaoui and Ben Rejeb, 2017) who revealed that the US stock market has a positive effect on oil and gold prices and (Syarif and Asandimitra, 2015) who disclose that oil prices have a significant positive effect on the IDX.

\section{Managerial Implications}

The fundamental factors determination shows the importance of control over financial ratios that need to be carried out by controlling and evaluating corporate spending, operational effectiveness, and cost-efficiency as steps the company can take in the organization. Managerial steps are needed in order to anticipate external factors, especially to deal with fluctuations in oil prices, changes in the Fed's interest rates, and world gold prices on FCX stock prices by conducting Good Corporate Governance by performing transparency, good cooperation between all stakeholders, the local community of the mining area, the regional government and the central government to be able to ensure the continuity of the mining operation so that positive market sentiments are formed for the company's going concern.

\section{CONCLUSIONS AND RECOMMENDATIONS}

\section{Conclusions}

Simultaneously Fundamental factors (NPM, ROA, ROE, EPS, WCTO) and external factors (The Fed rate, gold price, oil price, beta, and government regulation) have a significant influence on the FCX stock price. Partially in the long term, only ROA in the fundamental factors has a significant positive effect on FCX stock prices while NPM, ROE, EPS dan WCTO have no influence on FCX Stock prices, this is different from external factors, almost all external factors in this research except beta have an significant influence on FCX stock prices. In the long term, The Fed Rate has a significant negative effect, gold prices have a significant positive effect, oil prices have a significant positive effect and government policy (dummy variable) has a significant negative effect.

In the short-term disequilibrium was corrected in the current period by $67 \%$. That is mean if there is a disturbance (shock) the adjustment process (Adjustment Mechanism Process) on the long-term equilibrium lasts for $1 / 0.672702=1$ quarter. ROE has a significant negative effect, WCTO has a significant positive effect meanwhile NPM, ROA, EPS have no influence on FCX Stock prices for the fundamental factors and in the external factors, gold price and the oil price has a significant positive effect while the Fed rate, beta and government regulation have no influence on FCX stock price

\section{Recommendations}

Based on the results of the analysis conducted in this study, there are several things that can be suggested for companies, investment actors, and academics:

1. Companies need to stabilize their operation, focus on the main industry (gold mining), have a good relationship with all shareholders especially the Indonesia government and minimize internal issues to anticipate things from outside and provide a positive sentiment for market

2. Investors need to observe the fluctuation in stock prices, the influence of fundamental factors, external factors, and shocks that occur based on previous information to make decisions to buy or release shares they owned as a form of risk control and stock diversification.

3. For academics, the authors suggest observing some more diverse variables and phenomena that occur that can affect stock prices as conducted in this study. This is suggested so that the conclusion and information obtained are more general and updated.

For the next research, the researcher provides suggestions to include variables related to PTFI's financial ratios, Corporate Social Responsible (CSR) programs, and prices of other commodities such as copper as part of the observation. 


\section{REFERENCES}

Alena E, Achsani NA, Andati T. 2017. Dampak guncangan variabel makroekonomi terhadap beta indeks sektoral di BEI. Jurnal Aplikasi Bisnis dan Manajemen 3(3):384-397. https:// doi.org/10.17358/jabm.3.3.384

Avdalović MS, Milenković I. 2017. Impact of company performances on the stock price: an emperical analysis on select companies in Serbia. Economics of Agriculture 64(2):561-570. https:// doi.org/10.5937/ekoPolj1702561M

Brigham EF, Housten JF. 2010. Essentials of Financials Management. 11th Ed. Translate by: Ali AY. Jakarta: Salemba Empat.

Broadstock DC, Filis G. 2014. Oil price shocks and stock market return: new evidence from United States and China. Journal of International Financial Markets, Instituions and Money 33:417-433. https://doi.org/10.1016/j.intfin.2014.09.007

Drobetz W, Menzel C, Schroder H. 2015. Systematic risk behavior in cyclical industries: the case of shipping. Transportation Research Part E: Logistics and Transportation Review 88(9):129145. https://doi.org/10.1016/j.tre.2016.01.008

Davis SJ, Haltiwanger J. 1999. Sectoral Job Creation and Destruction Responses to Oil Price Changes. Cambridge: National Bureau of Economic Research, Massachusetts Avenue. https://doi. org/10.3386/w7095

Djalil MA, Tabrani M, Jalaludin. 2016. The Effect of Earnings per Share, Book Value, and Systematic Risk on Equity Valuation in Manufacturing Company Listed on Indonesia Stock Exchange for The Year 2011-2014. In Rothschild, J and Cermakova, K (Ed.s). Proceedings of the 25th International Academic Conference; Prague, 6-9 Sept 2016. Prague: OECD Headquarters in Paris, International Institute of Social Economics Sciences. https://doi.org/10.20472/ IAC.2016.025.016

Durham JB. 2005. More on monetary policy and stock price returns. Financial Analysts Journal 61(4):83-90. https://doi.org/10.2469/faj.v61. $\mathrm{n} 4.2745$

Duggal R, Budden M. 2015. Further evidence of the creation of value through the management of net working capital: An analysis of S\&P 500 Firms. Journal of Business and Economics Research 13(1):79-82. https://doi.org/10.19030/jber. v13i1.9083
Egam GEY, Ilat V, Pangerapan S. 2017. The influence of return on asset (ROA), return on equity (ROE), net profit margin (NPM), and earning per share (EPS) toward LQ45 index in Indonesia stock exchange for period of 2013-2015. Jurnal EMBA 5(1):105-114.

Firdaus M. 2011. Aplikasi Ekonometrika. Bogor: IPB Press.

Gujarati, D. 2004. Basic Econometric. New York: The McGraw-Hill.

Haghiri A, Haghiri S. 2012. The investigation of effective factors on stock return with emphasis on ROA and ROE ratios in Tehran stock exchange (TSE). Journal of Basic and Applied Scientific Research 2(9):9097-9103.

Harun SM. 2002. The impact of monetary policy on equity markets and financial institutions [dissertation]. Louisiana: University of New Orleans.

Hatta AJ, Dwiyanto BS. 2012. The company fundamental factors and systematic risk in increasing stock price. Journal of Economic Business and Accountancy Ventura 15(2):245256. https://doi.org/10.14414/jebav.v15i2.78

Hidayat AK, Firdaus M, Sanim B. 2019. Pengaruh kapitalisasi pasar saham dan variabel makroekonomi terhadap Indeks Harga Saham Gabungan di Bursa Efek Indonesia. Jurnal Aplikasi Bisnis dan Manajemen (JABM) 5(2):332-332.https://doi.org/10.17358/ jabm.5.2.332

Horne JCV. 2002. Financial Management Policy. 12th Ed. United States: Prentice Hall.

Iqbal NS, Khattak. Khattak M. 2013. Does fundamental analysis predictstock returns? Evidence fromnonfinancial companies listed on KSE. Knowledge Horizons - Economics 5(4):182-190.

Joshi VK. 2012. Impact of fluctuation: stock/forex/crude oil on Gold. SCMS Journal Indian Management 96-114.

Juanda B. 2012. Ekonometrika Deret Waktu. Bogor: IPB Press.

Kazi MH. 2008. Systematic risk factors for Australian stock market returns: A cointegration analysis. Australian Accounting Business and Finance Journal 2(4):89-101. https://doi.org/10.14453/ aabfj.v2i4.6

Kothari SP. 2001. Capital market research in accounting. Journal of Accounting and Economics 31:105-231. https://doi.org/10.1016/S01654101(01)00030-1 
Manoppo VCO, Tewal B, Arazzi BHJ. 2017. The effect of current ratio, DER, ROA, and NPM on stock price of food and beverages listed in BEI (Period 2013-2015). Jurnal EMBA 5(2):1813-1822.

May E. 2011. Smart Traders Not Gamblers. 20th Ed. Jakarta: Gramedia Pustaka Utama.

Mumtaz MZ, Smith ZA. 2019. Examining spillover effect os US monetary policy to European stock markets: A markov-switching approach. Estudios de Economica 46:89-124.

Nison S. 2003. The Candlestick Course. Translate by: Waskito S. Jakarta: Elex Media Komputindo.

Park J, Ratti RA. 2008. Oil price shocks and stock markets in the U.S and 13 European countries. Energy Economic 30:2587-2608.

Pudji A. 2017. The influence of fundamental factors and systematic risk to stock prices on companies listed in the Indonesian stock exchange. European Research Studies Journal 20:30-240.

Raharjo D, Muid D. 2013. Analysis of fundamental factors effect in financial ratios toward stock prices. Diponogoro Journal of Accounting 2(2):1-11.

Raraga F, Muharam H. 2014. VAR Analyisis on Mutual Relationship Between Stock Price Index and Exchange Rate and The Role of World Oil Price and World Gold Price. Proceeding 11th Ubaya International Annual Symposium on Management. Surabaya: University of Surabaya.

Sakinah E, Chumaidiyah E, Zulbetti R. 2016. Analysis of profitability ratio and macroeconomic factors to stock return and SWOT strategy - case study: Mining sector companies listed in Indonesia stock exchange year 2010-2014. e-Proceeding of Engineering 3(2):2742-2750.

Sadorsky P. 1999. Oil price shock and stock market activity. Energy Economics 21:449-469.

Sha TL. 2017. Effects of price earning ratio, earning per share, book to market ratio and gross domistic product on stock price of property and real estate companies in Indonesia stock exchange. International Journal of Economic Perspectives 11:1743-1754.

Singh G. 2015. The relationship between exchange rate and stock price in India: An empirical study. The IUP Journal of Financial Risk Management 12(2):18-29.

Srinivasan P, Prakasam K. 2014. Gold price, stock price, and exchange rate nexus: The case of India.
The IUP Journal of Financial Risk Management 11(3):52-63

Subing HJT, Kusumah RWR, Gusni. 2017. An empirical of internal and external factors of stock pricing; evidence form Indonesia. Problem and Perspectives in Management 15(4):178-187.

Subeniotis DN, Papadopoulus DL, Tampakoudis IA, Tampakoudi A. 2011. How inflation, market capitalization, industrial production and the economic sentiment indicator affect the EU12 stock markets. European Research Studies 14(1):103-117.

Sulistyorini DD, Hartoyo S, Andanti T. 2015. Economic sector portfolio optimization in the commercial and retail segments. International Journal of Administrative Science \& Organization 22(1):36-50

Sumiyana S. 2007. Behavior of stock price variability over trading and nontrading periods, and daily return volatility. Gadjah Mada International Journal of Business 9(3):409.

Sumiyana, Baridwan Z, Sugiri S, Hartono JM. 2010. Accounting fundamentals and the variation of stock price: Factoring in the investment scalability. Gadjah Mada International Journal of Business 12(2):189-229. https://doi. org/10.22146/gamaijb.5508

Syarif MM, Asandimitra N. 2015. The influence of macroeconomic indicators and global factors on the composite stock price index (IHSG). Journal of Management Studies 9(2):144-156.

Tatom JA. 2002. Stock prices, inflation and monetary policy. Business Economics 37(4): 7-19.

Toraman C, Başarır C, Bayramoğlu MF. 2011. Determination of factors affecting the price of gold: A study of MGARCH model. Business and Economics Research Journal 2(4):37-50.

Visconti RM. 2018. Corporate profitability: return on equity, return on investment, Modigliani \& Miller proposition II and economic value added. SSRN Electronic Journal. Http://dx.doi.org/ 10.2139/ssrn.3144286

World Bank. 2020. Global Economic Prospect - Slow Growth, Policy Challenges. a World Bank Group Flagship Report.

Wijaya RF. 2014. Investasi Saham Ala Swing Treder Dunia. Jakarta: PT Elex media Komputindo.

Zubir Z. 2011. Manajemen Portofolio: Penerapannya dalam Investasi Saham. Jakarta: Salemba Empat. 